\title{
PER
}

\section{MULTILINGUAL EDUCATION IN KAZAKHSTAN AND MODEL OF MULTILINGUAL EDUCATION IN THE EUROPEAN CONTEXT}

\author{
Bakhyt Aubakirova, Kinga M. Mandel, Balázs Benkei-Kovács
}

\begin{abstract}
This article is dedicated to the issues and notion of multilingualism, particularly in Kazakhstan. Kazakhstan is a multiethnic country where more than 130 different ethnic groups reside. Currently, a fast multilingual advancement is taking place in Kazakhstan. The study explores the origins and definitions of multilingualism, role of multilingualism in the development of the Kazakhstani education system, the models of multilingual education in Kazakhstan. Different approaches and definitions in terms of multilingualism and the performance and implementation of multilingual education are presented The development of multilingual education in the Kazakhstani educational system plays a pivotal role and it is developing rapidly. The implementation of multilingual education in this country aims at integrating and internationalization of Kazakhstan to the world's educational and scientific societies. Multilingualism is also widespread in some of the European countries. Several approaches related to the multilingualism and multilingual education is indicated in this article, which are all rooted in specific national-historical-political contexte. This paper introduces the challenges and suggestions of diverse alternatives of multilingual education in Kazakhstani higher education institutions.
\end{abstract}

Keywords: multilingualism, multilingual education, international good practices, comparative analysis

\section{Models and definitions of multilingual education}

Nowadays multilingualism and multilingual education have rapidly been developing. Multilingualism is becoming one of the most significant foci in the European Union's policy. The focus is mainly paid to the implementation of multilingualism and its semantic part development in European countries. One of the basic issues of multilingual policy is language and cultural diversity among member states (Krzyżanowski and Wodak, 2011).

The poser of multilingualism is so important that it was reflected in the policy documents of the European Commission where it's relevant issues were talked much. The key document of "The New Framework Strategy for Multilingualism" (European Commission 2005) reasons "commitment to multilingualism in the European Union" and for "promoting multilingualism in European society, in the economy and in the Commission itself". This document also indicates multilingual promotion in different fields embracing the social, economical and other spectrums (Krzyżanowski and Wodak, 2011).

Krzyżanowski and Wodak (2011) explore the semantic field of multilingualism in the framework of European Union policy in different periods of time and describe each semantic development of multilingualism differently depending on time. Figure 1 illustrates Multilingualism that embraces "mother tongue" and several other domains related to the foreign language learning. Learning foreign language and language skills and motivation in this field shapes the economic and employment issues of the countries allowing people to increase the mobility in employment and economy as well. By creating this model, the Lisbon strategy has already an impact on language policy and multilingualism through the description of language skills and foreign languages. 
According to the European Commission (2000b: 8) in the frame of European countries it is normal the use three languages and the knowledge of languages allow people move among the nations for different purposes involving educational, professional reasons.

One of the most significant reasons for choosing the given model of semantic field of multilingualism in EULMP is that to our mind, it seems to be more applicable in the context of Kazakhstani multilingualism policy development and multilingual education system. The project of "Trinity of Languages" might serve as one of the economic reasons for multilingualism policy development in Kazakhstan. The implementation of multilingual education reform in educational institutions may serve as the possibility for further investment and the employment growth.

The most important priority in the given model is the involvement of "mother tongue" which in Kazakhstani context is regarded as a must while integrating and implementing multilingual education. The core reason for multilingualism policy in Kazakhstan is the achievement of mother tongue knowledge which means that through multilingual education we can enhance the knowledge and use of Kazakh language (mother tongue). At the same time the utmost attention is paid to acquiring foreign languages and now Kazakhstan is working hard on the development of learning foreign languages that embraces the implementation and practicing of different kinds of learning methods, language skills and the significance of foreign language use.

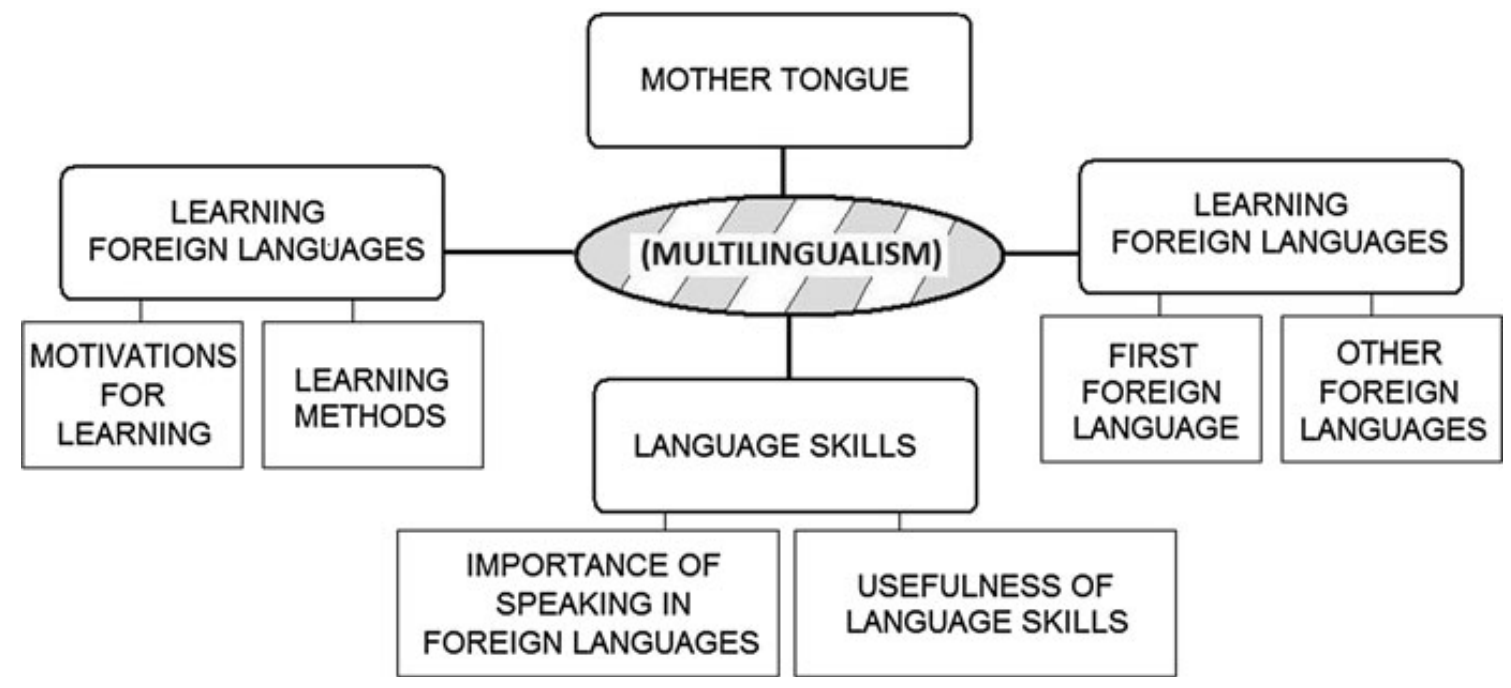

Figure 1. Semantic field of multilingualism in EULMP in 2000 (Krzyżanowski and Wodak, 2011).

According to the European Commission (2005) Multilingualism is designated as "a person's ability to use several languages and the co-existence of different language communities in one geographical area." Moreover, the Commission's long-term task is to teach at least two foreign languages and enlarge individual multilingualism because everyone should acquire practical skills on foreign languages including their mother-tongue (European Commission, 2005). In accordance with the European Commission (2005) they elaborated a strategy with a number of key fields for action in education system and practices that contain national strategies emphasizing the "need for national plans to give coherence and direction to actions to promote multilingualism amongst individuals and in society generally".

\section{National examples of European multilingual education}

A significant example of multilingual education systems is essential to research the Nordic countries (Denmark, Finland, Norway and Sweden) because of their multilingual developments.

Finland is regarded as one of those countries that possesses two (Swedish and Finnish) official languages (Bjorklund, Sjoholm, 2013). Denmark, Norway, Finland and Sweden participate in Network for Researchers of Multilingualism and Multilingual education, RoMME (2011-2013) in order to develop multilingual policy in all of these states. Notwithstanding a huge amount of similarities in these four countries they also have the differences in the development of language programs, language of language 
use. In order to develop such a complicated task the network of researchers in Nordic countries try to organize the congregations for the researchers involving the graduate and post-doctoral researchers, lecturers and experts in identifying the advantages and disadvantages of multilingual education (Bjorklund and Bjorklund, Sjoholm, 2013).

All these four Nordic countries have similar language learning system in primary schools and their compulsory education is prolonged to nine years. Foreign language learning in theses countries starts mostly from the primary education level as it is pointed out in the Table 1. As it is indicated in the Table 2 English language is considered to be the predominant language among the others and most of the learners choose English as their first foreign language in spite of that it is obligatory for them to study other national language (Ibid).

Table 1 . The general national frames of foreign language in primary education

\begin{tabular}{|c|c|c|c|c|}
\hline \multirow{2}{*}{$\begin{array}{l}\text { Foreign language } \\
\text { education in } \\
\text { comprehensive } \\
\text { school (in general) }\end{array}$} & Denmark & Finland & Norway & Sweden \\
\hline & $\begin{array}{l}\text { English } \quad \text { grade } 3 \text { )+ } \\
\text { another } \\
\text { (grade } 7)\end{array}$ & $\begin{array}{l}\text { English (grade } 3 \\
\text { or } 4 \text { ) + the other } \\
\text { national } \\
\text { language (grade } \\
7 \text { or } 3 \text { ) } \\
+1 \text { optional } \\
\text { language (grade } 8 \text { ) }\end{array}$ & $\begin{array}{l}\text { English (grade 1 } \\
\text { or 3) + another } \\
\text { language (grade 7) }\end{array}$ & $\begin{array}{l}\text { English (grade } \\
\text { 1) + another } \\
\text { language (grade } \\
\text { 6) }\end{array}$ \\
\hline
\end{tabular}

Source: Bjorklund and Bjorklund, Sjoholm, (2013)

As it is shown in (see Table 1), the development of foreign language education in comprehensive school illustrates that the languages are added gradually, parallel and simultaneously with each other. Nordic countries disseminated the syllabuses for integrating and teaching of national minority languages (NML) as a mother tongue in addition to the foreign language program. In spite of that all these four Nordic countries have the same research area they put much effort on developing the languages differently. It is in Norway's interest to develop national language teaching for immigrants in order to be able to use the national study programs (Bjorklund and Bjorklund, Sjoholm, 2013). We should state here that multilingual education in Nordic communities was developed and spread from the early school environment.

International experience in multilingual education demonstrates two basic groups of multilingual education: weak and strong. The first means the usage of only one language whereas the latter implies the implementation and fluency in several languages. Out of 178 multilingual countries in the world, only five have implemented multilingual education successfully.They are Finland, The Netherlands, Switzerland, Spain (The Basque country) and Luxemburg (Irsaliyev, Karabassova, Mukhametzhanova, Adil, Bekova and Nurlanov, 2017). Let us consider the development of multilingual education in the Finnish schools and the way they allocate time for language learning ${ }^{1}$ (Figure 2).

Success factors behind the Finnish model, in general, it is important to point out that in case of Finland the key points of multilingual education development are the right time arrangement of language learning in school grades and the high expenditure on education. More to this point, future teachers get compulsory subject blocks on multilingualism as a part of their academic program. The implementation of Content and Language Integrated Learning (CLIL) involving the universities where they acquire 50\% of subjects in English on multilingual education theory and practice is an additional element that addresses multilingualism. Thus after the graduation of secondary school most of the students are already competent in four languages embracing Finnish, English, Swedish, German and French. Ranging from $40 \%$ to $70 \%$ of subject content is taught in English within five years (Irsaliyev et al., 2017, p.151).

\footnotetext{
${ }^{1}$ In the case of Finland, five languages are in use involving $97 \%$ of population speaks Finnish, $45 \%$-English, 34\% -Swedish, 13\%-German and 3\%-French. The experience of Finland on multilingual education can be traced starting from the preschool education to higher education. Students in educational organizations have the right to choose the language of instruction (Finnish or Swedish) and As Finnish and Swedish are regarded as official languages the education is provided in both languages (Irsalyiev, 2017).
} 


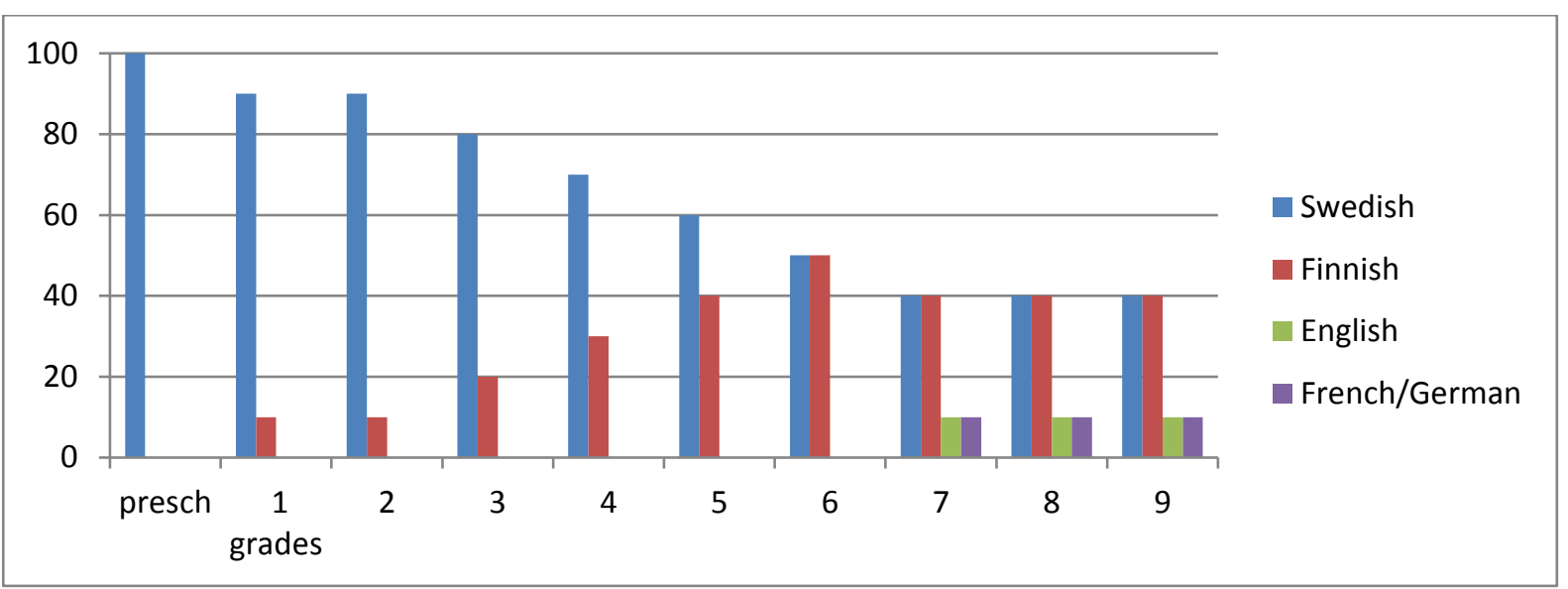

Figure 2. The multilingual education model in Finnish schools with time allocation for each language, \%. Source: Teaching in three languages: International experience and recommendations for Kazakhstan (Irsaliyev et al., 2017, p. 149).

\section{Multilingual education in European higher education institutions}

English language is regarded as the language of globalization and higher education institutions are competing in the world level as English became the global lingua franca (Doiz, Lasagabaster and Sierra, 2013).

"The real meaning of globalization is multilingualism" (Shohamy 2007, p.132). The case of higher education is varying in comparison with the schools. English language is regarded as the predominant language among the higher education institutions and in the scientific field. All the basic domains of higher education (scientific research, education and community services) are provided mostly by means of English language notwithstanding the merits of national languages in Flanders they applied to utilize English almost in every aspect. For instance in the context of Brussels higher education they implemented both Dutch and French as the language of instruction but The Flemish Ministry of Education permitted to use English in specific situations such as courses conducted by the international professors, programs and trainings for foreign students (Janssens, Mamadouh and Maracz, 2013).

The French community tends to arrange curriculum in English and it leads to the frequent usage of this language in all three cycled levels of education such as bachelor, master and post-academic degrees). Furthermore, the European Union plays a pivotal role in it while initiating different international programs for student exchange like Erasmus or Marie Curie which results in the enhancement of English language use developing the mobility settings among both students and teachers (Janssens, Mamadouh and Maracz, 2013).

Janssens., Mamadouh and Maracz (2013) exemplify that there are the cooperation of a French speaking (Université Libre de Bruxelles) and Dutch speaking (Vrije Universiteit Brussel) universities in Brussels which provide trilingual (French, Dutch and English)education for the civil engineers. However, in spite of such good prestige of universities the Flemish Ministry of Education insists on that all the teaching staff who teaches in English language should prove their language proficiency according to the European standard $\mathrm{C} 1$ by passing tests. Moreover foreign invited professors should also obtain B2 level of Dutch language in order fit to their environment (Janssens., Mamadouh and Maracz, 2013).

As for the case of Finland there are a number of higher education institutions where multilingual education is spread. For example, University of Vaasa and Abo Akademy provide teacher training in two stages: undergraduate - 180 ECTS and Masters - 120 ECTS. The subjects on multilingualism, pedagogy and major subjects are considered to be compulsory. In Abo Akademy the students learn three credits on the theory of multilingual education and two credits go to the practice of multilingual education and $50 \%$ of these subjects are taught in English language (Irsaliyev et al., 2017).University Oulu and University of Jyvaskyla provide 40-70 \% of teaching in English in the 5-year CLIL teaching. In addition, the University of Helsinki and University of Turku also contribute to CLIL trainings for teachers a lot (p.151). 
Having analyzed Finland's contribution to the development of multilingual education in higher education institutions it is apparent that much effort is spent for the provision of multilingual teaching staff and more credits for university students. While providing teachers with CLIL education and at the same time the universities facilitate multilingual subject blocks for students starting from the beginning of university education most percentage of which is supplied in English language.

Another example of multilingual education in higher education institutions refer to the case of Basque Country. Doiz, Lasagabaster and Sierra (2013) argue that it will be helpful to analyze one particular multilingual university in order to understand its picture. If to exemplify we can take Basque autonomous community that have the University of Basque Country which is estimated to be the bilingual one. This country witnesses the usage of two official languages such as Spanish, the majority and minority one is the Basque language. The given university also witnessed language policy development that comes together with internationalization process. It brought about three strategic actions and the first was dedicated to the development of student exchange and academic mobility, teaching staff mobility. The second one was dedicated to the international network, research and university-wide involvement settings. The latter encompasses the production of multilingualism program which was launched in 2005-2006 and approved by the Governing Council. In the frame of multilingual program students are enabled to enroll for the courses conducted in foreign languages (Doiz, Lasagabaster and Sierra, 2013). There are several objectives of multilingualism program of the Basque University:

to proceed at tertiary level with experimental trilingual level utilized at pre-university level (Basque, Spanish and English used as languages of instruction);

to enhance students' foreign language skills and to conduct research in foreign language;

to develop students' work;

to adjust the pursuit of postgraduate degrees abroad;

to engage foreign students and teaching staff.

There were three paralleled groups in above-mentioned three languages with the subjects in three languages in this university within the multilingualism program framework. Students have the right to choose in what language to study and what compulsory specific subject to choose. However the optional courses are taught only in one of these languages. In 2010-2011 the University of Basque Country witnessed that in the frame of multilingualism program the number of students increased 1300 students and over 400 qualified teaching staff that acquired the indispensable level (C1) of official language proficiency (Doiz, Lasagabaster and Sierra, 2013 p. 1409).

\section{State policy on Kazakhstani multilingual education}

The initiative of what the head of the state has entitled "The Trinity of languages" in Kazakhstan was introduced in 2004. After two years in 2006 during the twelve's session of the Assembly of the people of Kazakhstan the President of the country emphasized the significance of knowledge of three languages which is essential for the country's future. Along with this the next step of implementing trilingual education was proposed in 2007 in the message of the President "New Kazakhstan in a new world" that involved the attraction of teaching staff from abroad and gradual implementation of trilingual education started (Address of the President of the Republic of Kazakhstan, Nursultan Nazarbayev, to the people of Kazakhstan, 2007).

In 2014 in the "Kazakhstani way-2050" declaration the leader of the country pointed out the necessity of the knowledge of three languages for the school leavers (Address of the President of the Republic of Kazakhstan N. Nazarbayev to the nation, 2014).

On the basis of "Trinity of Languages" project the "State Program of functioning and development of languages for 2011-2020" ('Decree of the President of the Republic of Kazakhstan №110', n.d.) is being carried out in three stages. The first stage starts from 2011-2013 and is dedicated to the usage of language development of measures in order to improve the regulatory and methodological basis. Second stage 
from 2014-2016 is devoted to the introduction and application of technologies, language teaching methods, language diversity safety and practical implementations. Third stage 2017-2020 witnesses the maintenance of other language usage, the necessity for the use of state language in public life and the absorption of the demand for the quality and the validity of the monitoring system results (State Program of functioning and development of languages for 2011-2020). According to the aims of the "State Program 2011-2020" of the Republic of Kazakhstan 95\% of the population should speak Kazakh, 90\% - Russian language and 20\% - English language (Toktamysova, 2012).

The implementation of the Roadmap for the development of trilingual education for 2015-2020 is aimed at updating the content of curricula at all levels of education. It aims to ensure the continuity of trilingual education in the context of a single educational environment; to improve the system of training and retraining of teaching staff for the effective implementation of trilingual education; and to ensure the effective research in the field of trilingual education in Kazakhstan, and the popularization of the cultural project "Trinity of Languages" (Zubko, 2017).

The Roadmap provides 7 strategic directions:

1. Improving the regulatory and legal framework for trilingual education;

2. Research activities on the study of problems of trilingual education;

3. Methodological and educational support of trilingual education;

4. Training and professional development;

5. Institutional support for trilingual education;

6. Information support of trilingual education;

7. Financing of trilingual education.

Currently, the new generation of Kazakhstan is fully being integrated and influenced by the multilingual education because it is now being implemented and added into the curriculum of higher education institutions. From the political aspect the recognition and implementation of multilingual education in the context of Kazakhstan are dependent on local administration. Multilingual policy is already enacted by the law and approved by the State Program 2011-2020.

\section{Pilot schools on Multilingual education in Kazakhstan}

Since 2007-2008 the multilingual education started by the initiative of the Kazakhstani Ministry of Education and Science (Kulsariyeva, Iskakova and Tajieva, 2017). First of all the implementation of multilingual education in three languages in the country began in three experimental bases including 33 "Daryn" pilot schools 20 NIS (Nazarbayev Intellectual Schools) and 30 BIL (Bilim Innovation Lyceums) of all educational levels in pilot mode. Both NIS and BIL use the strong model of trilingual education while implementing three languages as instruction languages (Irsaliyev et al., 2017, p.135). These schools presented the study process in Kazakh, Russian and English embracing the STEM subjects trained in English (Kulsariyeva, Iskakova and Tajieva, 2017).

NIS and BIL have their own system of integrating the languages of instruction from the definite period of time for example, BIL adopt lately Kazakh language from the 9th grade whereas NIS provide their learners with English language for language instruction and BIL start using English language instruction only after the language preparation (Irsaliyev et al., 2017). NIS and BIL schools are considered to be piloting schools of multilingual education. In 2019 the implementation of trilingual education will start in the other public and mainstream schools based on the experience of the above mentioned piloting schools (Irsaliyev et al., 2017). 
Table 3. The amount of academic load of language subjects at schools (Irsaliyev et al., 2017).

\begin{tabular}{|l|l|l|l|}
\hline Schools & Week load & Expected level of L2 & Expected level L3 \\
\hline $\begin{array}{l}\text { NIS (Nazarbayev } \\
\text { Intellectual school) }\end{array}$ & $4-5$ hours & C1 & C1 \\
\hline $\begin{array}{l}\text { BIL (Bilim Innovation } \\
\text { Lyceums) }\end{array}$ & $4-5$ hours & B2, C1 & B2 \\
\hline Mainstream schools & $2-3$ hours & B1 & B1 \\
\hline
\end{tabular}

Source: Teaching in three languages: International experience and recommendations for Kazakhstan (Irsaliyev et al., 2017)

NIS prepares their learners for 4 year extensively for instruction in English language whereas in BIL they began to teach only after four months of intensive language training (Ibid).

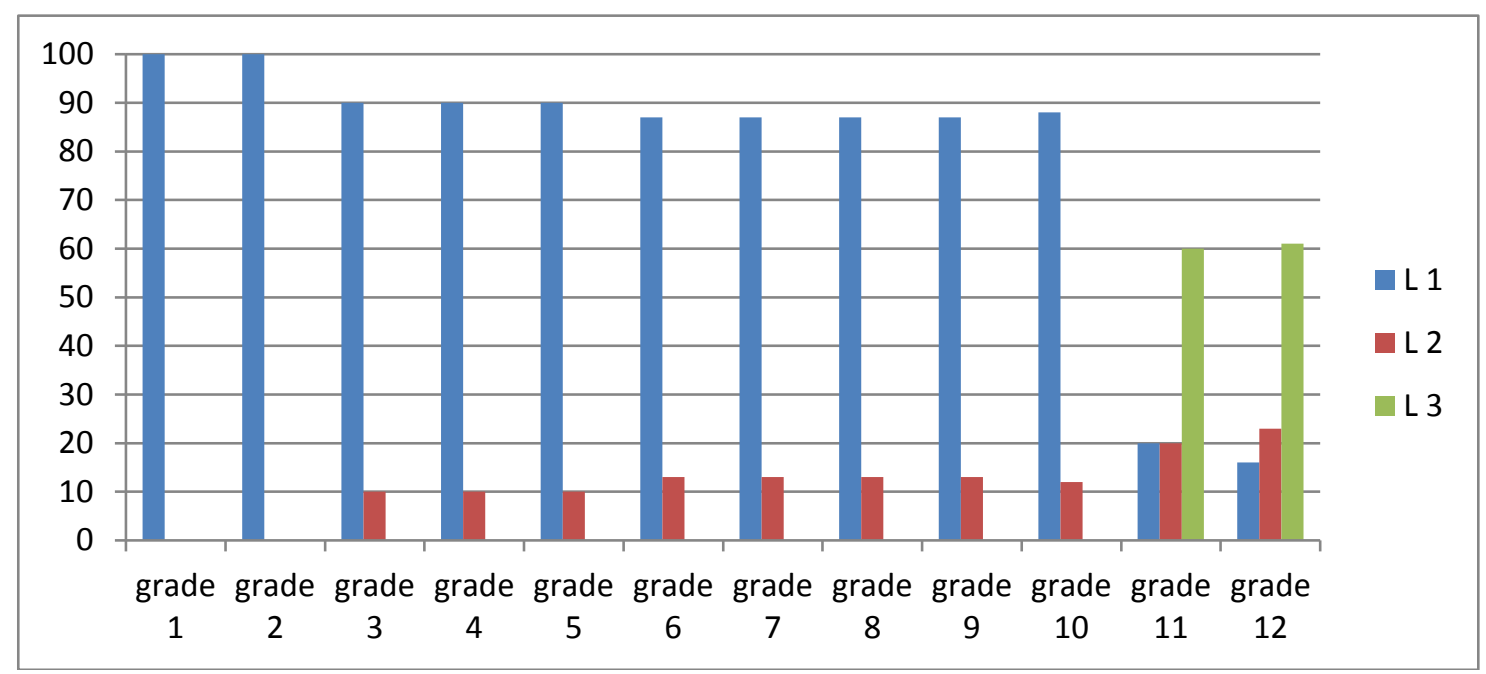

Figure 3. Model of trilingual education in NIS with time allocation for each language, $\%$

Source: Teaching in three languages: International experience and recommendations for Kazakhstan (Irsaliyev et al., 2017)

As it is illustrated in Figure 3 the model of trilingual education in NIS keeps the early immersion of the first language until the grade twelve. Native speakers, implementing bilingual team teaching are carrying out teaching in this type of schools. In teaching English they provide the learners with four year extensive language training and therefore by the end of school completion they are to possess $\mathrm{C} 1$ level of English. More to this point the learners are encouraged to be engaged in extra curricula activities in English language (Irsaliyev et al., 2017, p.137).

As NIS and BIL schools are regarded as the piloting ones they have different kinds of multilingual education development strategies and models, grading systems and various time allocations for integrating all three languages. They are even facilitated by different curriculum. Those hopefully will show the right procedure and results and contribute to choose which pilot mode to apply to the other mainstream schools (Sagyndykova, Svinarchuk and Kubrina, 2017).

\section{Multilingual education in Kazakhstani higher education institutions}

There are three main basis of State Policy in the field of higher education in Kazakhstan the Constitution of the Republic of Kazakhstan (RK), the "Law on Education" (2017), and "State Program of Education Development for 2011-2020", accordingly higher education is open to those who have finished general secondary, technical and vocational education or continuing education.

"Law on Education", first launched in 1999, is the core and primary law ensuring general framework for higher education institutions in Kazakhstan to designate its strategy for development. Additionally, this law attempts to shape new national model for the country's educational system and it presents principles of the State Policy in the field of particularly higher education. 
The Higher Education World Declaration in 21st century in accordance with UNSECO, (1998) indicates the key point of integrating and developing multilingual education in higher education institutions such as "the practice of multilingualism, teaching staff and students exchange program should be an integral part of all higher education systems" (Article 15) cited in (Kulsariyeva, Iskakova and Tajieva, 2017). Multilingual learning program provides the foundation of new models of education placing the language culture in the centre. Currently, the actions towards the implementation of that new education model in Kazakhstani higher education is being penetrated. This includes the transformation of educational standards, the arrangement of a number of departments in the universities are being implemented where polylingual teaching environment provides education using three languages (Toktamysova, 2012).

There are one hundred and twenty-five higher education institutions in Kazakhstan. The most part of these higher education institutions 54 belongs to private ones and the other 16 are corporatized, 1 international, 31 non-civil, 9 national and one is Autonomous (Nazarbayev University) (Higher education in Kazakhstan).

Sagyndykova, Svinarchuk and Kubrina(2017) give a detailed statistics of the multilingual education development and describes it starting from 2012 - 2013 academic year 32 higher education institutions (HEI) in Kazakhstan opened specific departments on multilingual education where the lessons are being conducted through English. In 2015 - 2016 the scope of those specific departments widened in 42 out of those 125 higher education institutions in the framework of trilingual education: 6 of them are national HEIs, 26 - State HEIs, 1- international HEI, 7-JSC HEIs and 2- private HEIs (Sagyndykova, Svinarchuk \& Kubrina, 2017). They point out that in 2015 - 2016 the amount of multilingual groups increased to 2393 in which 18006 people are studying: 16121 students are studying - in bachelor degree, 1662 - in postgraduate education and 223-in graduate education (Sagyndykova et al., 2017).

The teaching staff in multilingual education consists of 2121 teachers who conduct lessons in English (Sagyndykova, Svinarchuk and Kubrina, 2017). In 17 universities training in three languages began since 2012. They conduct teacher preparation in Biology, Chemistry, Physics and ICT in English as a medium of instruction. Since 2016 there is a transformation to the model of multilingual education "50:20:30" which means (50\% of subjects are conducted in first language, $20 \%$ in second language and $30 \%$ in third one) (Irsaliyev et al., 2017, p.139).

Having researched the above mentioned details of multilingual education development in Kazakhstani higher education institutions it is noticeable that trilingual education is rapidly advancing. Almost one third of Kazakhstani higher education institutions are implementing and penetrating multilingual education which shows the significance and relevance of multilingual setting development on the national scope. Furthermore, in accordance with Toktamysova (2012) the multilingual education implemented in Kazakhstani higher education is the unique program that embraces the conduction of trainings parallel and simultaneously in three languages (Kazakh, Russian and English). She also emphasizes that all the works connected to the formation of multilingual personality in the roles of multilingual teachers and different kinds of teacher trainings and preparations involving multilingual education is accomplished and supported by the Ministry of Education and Science (MES of RK) (Toktamysova, 2012).

The rapid development of multilingual education in Kazakhstani higher education institutions may cause some challenges as well. As it is regarded to be new model, educational institutions face the lack of teaching materials and staff in English language. For example Kazakhstani scholars, Sagyndykova, Svinarchuk and Kubrina (2017) indicate that the whole elaboration and organization of teaching materials in Kazakhstani higher education system are prepared by the universities themselves. Special teaching staffs who conduct lessons in multilingual groups on a specific area for example, chemistry, Biology in Kazakh or Russian languages usually fulfill the procedure of the teaching materials preparation. The new materials and manuals, online courses, dictionaries in three languages, glossaries elaborated in Kazakh or Russian are translated and reviewed into English language by the teachers of English in the English language department (Sagyndykova, Svinarchuk and Kubrina, 2017). It means that the most significant challenges in multilingual education in Kazakhstani higher education institutions are the lack of teaching staff with English knowledge proficiency. Due to the paucity of 
multilingual teachers all around Kazakhstan but even though in the capital city and other megacities there are a number of professors from abroad who work in Kazakhstani higher education institutions.

According to Irsaliyev et al., (2017) one model of trilingual education in Kazakhstan is devoted to KarSU and a different for the other universities where multilingual education is being developed and expanded. In Kazakhstani higher education the undergraduate (bachelor) education takes four years of study thus there are a total of eight semesters to fulfill for the students.

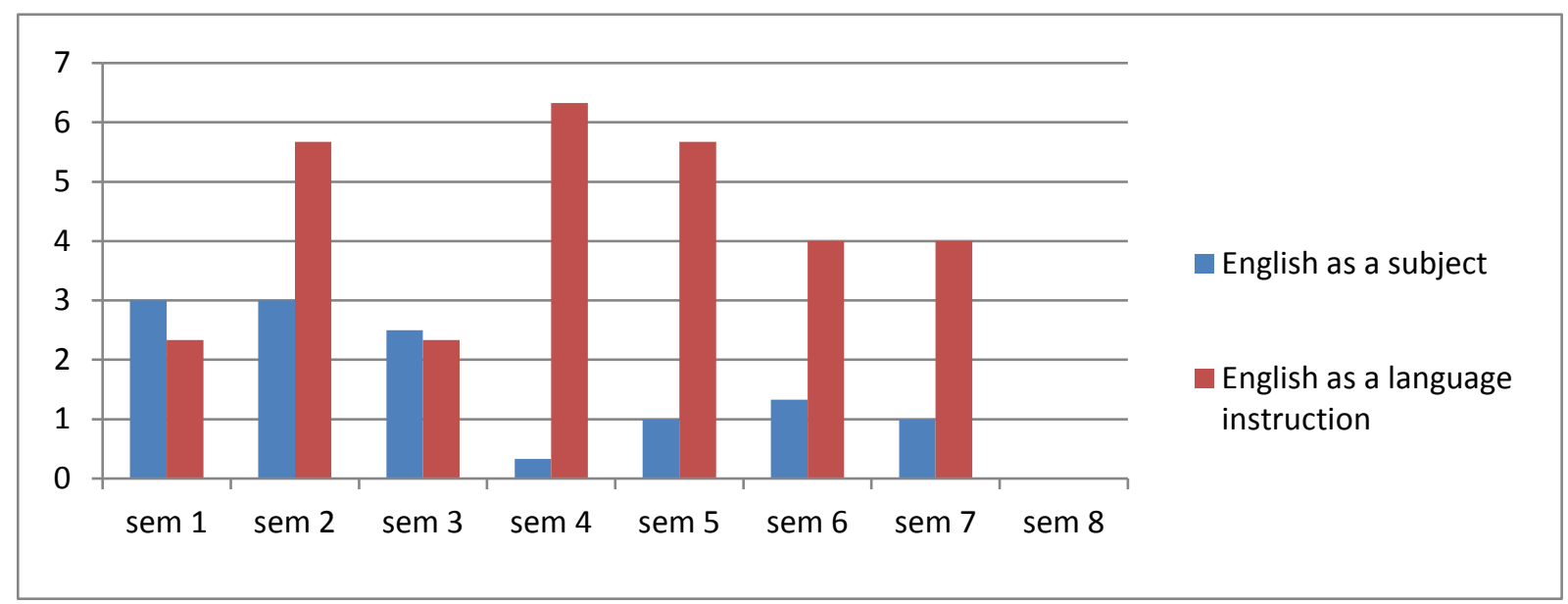

Figure 5. Model of trilingual education in universities (average), Academic load (credit numbers)

Source: Teaching in three languages: International experience and recommendations for Kazakhstan (Irsaliyev et al., 2017, p.141).

In the trilingual education model of other universities, as it is illustrated in the diagram (see Figure 5) they strive to keep it somehow altogether by allocating credits both for English as a subject and for subjects with English as a language of instruction. Implementation of English as a language of instruction starting both from the first semester may lead into the deterioration of students' internalization on those specific subjects due to the lack of language proficiency of students. In the meantime gives the advantage that they will provide with the credits for English as a subject until the end of their graduation. That contributes the students to support and enhance their knowledge of language that will lead to the better subject cognitions. Even though this kind of model can be a plus factor for trilingual education integration to make students to study for example Biology, Chemistry etc from the beginning in English language. But at the same time it can cause problems concerning the students' understanding of subject in English due to the lack of students English language competence.

\section{Conclusion}

Multilingualism, is a solid experience of European countries but Kazakhstan has chosen its own way of develop trilinguality - multilinguality. Such a development and intervention of multilingual education may serve as an implication for the multilingual education system of Kazakhstan and as the best practices for usage. Notwithstanding the best experiences of above-mentioned European multilingual countries the case of Kazakhstan in this field still remains heterogeneous because of cultural diversity and various language backgrounds but nevertheless we opine that Kazakhstan can somehow benefit from these approaches too, taking in consideration the national policy contexte. Although with the thoroughly elaborated policy the education system encounters a variety of issues: lack of teaching staff, lack of teaching resources and aids. However, time by time with the development of teaching resources, the teaching environment is getting more favorable for multilingual education. Multilingual education is an unique educational policy reform in Kazakhstan in comparison with the other multilingual nations. Any reform requires ongoing long period of time to achieve results. It is advisable to continuously follow and measure its development and implement changes whenever a correction would be needed.

All in all due to a great variety of multilingualism and multilingual education development models this paper sets a number of insights for the practitioners and researchers in the frame of comparing successful 
experiences in the field of multilingualism in different contexts may serve as the possible alternative for the case of Kazakhstan in developing multilingual education.

\section{Bibliography}

Baetens-Beardsmore, H. (2001): Foreword: The past decade and the next millenium. In D. Marsh; A. Maljers; A. Hartiala (Eds.). Profiling European CLIL Classrooms. UNICOM: University of Jyväskylä \& European Platform for Dutch Education, 10-11.

Biseth, H. (2009): Multilingualism and education for democracy. International Review of Education, 55(1), 5-20.

Björklund, M., Björklund, S., \&Sjöholm, K. (2013): Multilingual policies and multilingual education in the Nordic countries. International Electronic Journal of Elementary Education, 6(1), 1.

Course towards the future: modernization of Kazakhstan's identity (2017): Retrieved from: www. akorda.kz

Coste, D., Moore, D., \& Zarate, G. (2009): Plurilingual and pluricultural competence. Language Policy Division. Strasbourg: Council of Europe.

De Angelis, G. (2007): Third or additional language acquisition(Vol. 24). Multilingual Matters.

de Saint-Georges, I., \& Weber, J. J. (Eds.). (2013): Multilingualism and multimodality: Current challenges for educational studies. Springer Science \& Business Media.

Doiz, A., Lasagabaster, D., \& Sierra, J. (2013): Globalisation, internationalisation, multilingualism and linguistic strains in higher education. Studies in higher education, 38(9), 1407-1421.

European Commission (2005): Communication from the Commission to the Council, the European Parliament, the European Economic and Social Committee and the Committee of theRegions: A New Framework Strategy for Multilingualism (COM 2005, 596 final). Retrieved from http://europa.eu/languages/en/document/74

European Commission 2007a: A political agenda for multilingualism. MEMO/07/80,Brussels, 23.02.2007.

Herzog-Punzenberger, B.; Le Pichon-Vorstman, E.; Siarova, H., 'Multilingual Education in the Light of Diversity: Lessons Learned', NESET II report, Luxembourg: Publications Office of the European Union, 2017. doi: 10.2766/71255.

Hillyard, S. (2011): First steps in CLIL: Training the teachers. Latin American Journal of Content \& Language Integrated Learning, 4(2), 1-12.

Higher education in Kazakhstan (2017), Retrieved from https://supporthere.org/page/higher-educationkazakhstan

Issabekova, G. B., Abdillaev, A. K., Kasymbekov, J. A., Altynbekov, A., \&Duysenov, O. (2016): Multicultural Education as a Factor of Formation of a Multicultural Personality. The Social Sciences, 11(22), 5360-5364.

Irsaliyev S.E., Karabassova L.Ch., Mukhametzhanova A.Z., Adil A.B., Bekova M.A.,\&Nurlanov Y.B. (2017) Teaching in three languages: International experience and recommendations for Kazakhstan. Astana: JSC "Information- Analytic Center".

Janssens, R., Mamadouh, V., \& Maracz, L. (2013): Multilingual higher education in European regions. ActaUniversitatisSapientiae, European and Regional Studies, 3, 5-23.

Kang, E. (2013): Multilingual competence. Teachers College, Columbia University Working Papers in TESOL \& Applied Linguistics, 13(2), 55-56.

Krzyżanowski, M., \&Wodak, R. (2011): Political strategies and language policies: the European Union Lisbon strategy and its implications for the EU's language and multilingualism policy. Language Policy, 10(2), 115-136. 
Kulsariyeva, A., Iskakova, A., \&Tajiyeva, M. (2017): Trilingual Education: An Effective Way of Providing Inclusion. European Scientific Journal, ESJ, 13(12).

Nation, R., \& McLaughlin, B. (1986): Novices and experts: An information processing approach to the "good language learner" problem. Applied Psycholinguistics, 7(1), 41-55.

OECD, (2015): Helping immigrant students to succeed at school- and beyond.

OECD (2017): Higher Education in Kazakhstan 2017. Reviews of National Policies for Education. OECD Publishing, Paris.

Ospanova, B. R., Azimbayeva, Z. A., Timokhina, T. V., \&Seydakhmetova, Z. K. (2016): Theoreticaland-Methodological Substantiation of Multilingual Model Activity in Kazakhstan Higher School Education System. International Journal of Environmental and Science Education, 11(10), 3450-3466.

Ramsay, R. M. G. (1980): Language-learning approach styles of adult multilinguals and successful language learners. Annals of the New York Academy of Sciences, 345(1), 73-96.

Saville-Troike, M. (2006): The psychology of second language acquisition. In Introducing second language acquisition (pp. 67-97). Cambridge, UK: Cambridge University Press.

SagyndykovaZh.O., SvinarchukA.I.,\&Kubrina T.A. (2017) Polylingvalnayakommunikaciya $v$ Kazakhstane:Rechevoe I tekstovoepredstavlenie [Polylingual communication in Kazakhstan: Speech and text production]Kokshetau: Publisher «Mirpechati».

Skutnabb-Kangas, T. (2000): Linguistic genocide in education--or worldwide diversity and human rights?. Routledge.

Teaching and Learning: Towards the Learning Society. (1995): European Commission's White Paper, 1995 Brussels: The European Union.

Toktamysova, A. (2012): Polylingualism is the Way to the Future. NazarbaevN.A.Social modernization of Kazakhstan:Twenty steps to Society General Work//“Kazakhstanskayapravda”, 218-219.

UkazPrezidentaRespublikiKazahstanot 29 Iyunya 2011 Goda№ 110 «O GosudarstvennoiProgramme Razvitiya I FunkcionirovaniyaYazykov V RespublikeKazahstan Na 2011-2020 Gody» (s Izmeneniyami I DopolneniyamiOt 04.12.2015 G.) [The Decree of the President of the Republic of Kazakhstan from 29 June 2011 № 110 "State Program of Language development and Functioning in The Republic of Kazakhstan 2011-2020" (modified and amended from 04.12.2015)] Retrieved from https://online.zakon.kz/document/?doc id=31024348\#pos=1;-251

Valdes, Guadalupe and Figueroa, Richard A. (1994): Bilingualism and Testing: A Special Caseof Bias. Norwood, NJ: Ablex Publishing.

Vázquez, V. P., \& Ellison, M. (2018): Examining teacher roles and competences in Content and Language Integrated Learning (CLIL). Linguarum Arena: Revista de EstudosemDidática de Línguas da Universidade do Porto, 4, 65-78.

Vez, J. M. (2009): Multilingual education in Europe: Policy developments. Porta linguarum, 12, 7-24.

Weinreich, U. (1953): Languages in Contact. The Hague: Mouton.

Xhaferi, B., \&Xhaferi, G. (2012): Teacher's perceptions of multilingual education and teaching in a multilingual classroom-the case of the Republic of Macedonia. Jezikoslovlje, 13(2), 679-696.

Yeskeldiyeva, B. Y., \&Tazhibayeva, S. Z. (2015): Multilingualism in modern Kazakhstan: New challenges. Asian Social Science, 11(6), 56.

Zubko, N. (2017): Road map for trilingual education as a strategic orientation of contemporary education. Retrieved from https://infourok.ru/dorozhnaya-karta-trehyazichnogo-obrazovaniyakak-strategicheskiy-orientir-sovremennogo-obrazovaniya-1674007.html 


\section{Authors}

Bakhyt Aubakirova, Eötvös Loránd University, Budapest (Hungary). E-mail: tolegen.bakhyt@ gmail.com

Kinga M. Mandel, Eötvös Loránd University, Budapest (Hungary). E-mail: mandel.kinga@ @pk. elte.hu

Balázs Benkei-Kovacs, Eötvös Loránd University, Budapest (Hungary). E-mail: benkeikovacs.balazs @ppk.elte.hu 